\title{
Quantitative and qualitative feed restriction for broilers
}

\author{
Restrição alimentar quantitativa e qualitativa em frangos de corte \\ Restricción cuantitativa y cualitativa de alimento en pollos de engorde
}

Received: 09/10/2021 | Reviewed: 09/17/2021 | Accept: 09/21/2021| Published: 09/23/2021

Thiago de Sousa Melo

ORCID: https://orcid.org/0000-0003-1862-9571 Universidade Federal da Paraíba, Brazi E-mail: thiagosoumelo@hotmail.com José Humberto Vilar da Silva

ORCID: https://orcid.org/0000-0001-8605-2829 Universidade Federal da Paraíba, Brazil E-mail: vilardasiva@yahoo.com.br

José Jordão Filho

ORCID: https://orcid.org/0000-0003-3964-9301 Universidade Federal da Paraíba, Brazil E-mail: jjordaofilho@yahoo.com.br

Fernando Guilherme Perazzo Costa ORCID: https://orcid.org/0000-0003-4075-1792 Universidade Federal da Paraíba, Brazil E-mail: perazzo63@gmail.com

Patrícia Emília Naves Givisiez

ORCID: https://orcid.org/0000-0002-2480-1780 Universidade Federal da Paraíba, Brazil E-mail: patricia@cca.ufpb.br

José Andrew de Lira Barbosa

ORCID: https://orcid.org/0000-0002-2655-2538 Universidade Federal da Paraíba, Brazil E-mail: andrew.lira980@gmail.com

Natalí Estevão da Cruz

ORCID: https://orcid.org/0000-0002-1671-2841 Universidade Federal da Paraíba, Brazil E-mail: nataliestevaocruz@hotmail.com

Laryssa Querino da Silva Duarte ORCID: https://orcid.org/0000-0002-9909-1058 Universidade Federal da Paraíba, Brazil E-mail: laryssaquerino@gmail.com Janiele Ferreira da Silva

ORCID: https://orcid.org/0000-0002-5140-8175 Universidade Federal da Paraíba, Brazil E-mail: janieledellety@hotmail.com

Veruska Dilyanne Silva Gomes ORCID: https://orcid.org/0000-0002-4169-2491 Instituto Federal de Educação, Ciência e Tecnologia do Tocantins, Brazil E-mail: veruska_sgomes@yahoo.com.br

\begin{abstract}
The objective of this study is to evaluate the influence of five feed restriction programs (FRP) on broiler performance and carcass yield. $425 \mathrm{Cobb} 500 \AA$ broilers were distributed in a completely randomized design with five FRPs and five replicates with 17 broilers. The FRPs were: Program $1\left(\mathrm{P}_{1}\right)$ : consumption ad libitum (AL) of control diet from 14 to 42 days; $\mathrm{P}_{2}$ : quantitative restriction (QTR) of $10 \%$ of AL consumption from 14 to 28 days and AL consumption from 29 to 42 days; $\mathrm{P}_{3}$ : AL consumption from 14 to 28 days and QTR from 29 to 42 days; $\mathrm{P}_{4}$ : qualitative restriction (QLR) of $10 \%$ of the level of crude protein and essential amino acids from 14 to 28 days and AL consumption from 29 to 42 days; and $\mathrm{P}_{5}$ : AL consumption from 14 to 28 days and QLR from 29 to 42 days. The broilers of the AL treatment gained more weight ( $\mathrm{p} \leq 0.01$ ), but had a similar FCR ( $\mathrm{P}>0.05)$ compared to broilers submitted to QTR from 29 to 42 days. In addition, broilers fed QTR from 14 to 28 days presented a lower FI and a better FCR ( $\leq \leq 0.01)$ in relation to broilers fed QLR of 14 to $28\left(\mathrm{P}_{4}\right)$ and 29 to 42 days $\left(\mathrm{P}_{5}\right)$. The broilers fed QTR of 14 to 28 days diet presented a similar FCR as broilers fed AL. The $10 \%$ reduction in AL consumption of 14 to $28 \mathrm{~d}$ is a viable economical alternative to feed broilers up to 42 days of age.
\end{abstract}

Keywords: Amino acids; Consumption; Economic analysis; Feedback. 


\section{Resumo}

Avaliou-se a influência de cinco programas de restrição alimentar (PRA) sobre o desempenho e características de carcaça de frangos. 425 frangos de corte Cobb 500® foram distribuídos em delineamento inteiramente ao acaso, com 5 PRA e 5 repetições de 17 aves cada. Os PRA foram: Programa $1\left(\mathrm{P}_{1}\right)$ : consumo ad libitum (AL) da dieta controle dos 14 aos 42 d de idade; $P_{2}$ : restrição quantitativa (RQT) de $10 \%$ do consumo AL no período de 14 a 28 d e consumo AL de 29 a 42 d de idade; $\mathrm{P}_{3}$ : consumo AL no período de 14 a 28 d e RQT de 29 a 42 d; $\mathrm{P}_{4}$ : restrição qualitativa (RQL) em $10 \%$ no nível de proteína bruta e aminoácidos essenciais de 14 a 28 d e consumo AL de 29 a 42 d de idade e $P_{5}$ : consumo AL no período de 14 a 28 d e RQL de 29 aos 42 d de idade. Os Frangos do tratamento AL ganharam mais peso ( $\mathrm{p} \leq 0,01)$, mas tiveram conversão alimentar (CA) (P>0,05) semelhante comparados aos frangos submetidos a RQT de 29 a 42 d. Além disso, frangos alimentados com RQT de 14 a 28 d apresentaram menor consumo e melhor CA $(p \leq 0,01)$ em relação ao grupo de frangos alimentados com RQL de 14 a $28\left(\mathrm{P}_{4}\right)$ e de 29 a 42 dias de idade $\left(\mathrm{P}_{5}\right)$. Os frangos da dieta de RQT de 14 a 28 d apresentaram semelhante CA em relação as aves alimentadas com a oferta AL. A redução em $10 \%$ do consumo AL de 14 a 28 d é uma alternativa econômica viável para alimentar frangos de corte até $42 \mathrm{~d}$ de idade.

Palavras-chave: Aminoácidos; Análise econômica; Consumo; Realimentação.

\section{Resumen}

Se evaluó la influencia de cinco programas de restricción alimenticia (PRA) sobre el rendimiento y las características de la canal de pollos de engorde. Se distribuyeron 425 pollos de engorde (Cobb 500®) en un diseño completamente al azar, con 5 PRA y 5 réplicas con 17 aves cada una. Los PRA fueron: Programa $1\left(\mathrm{P}_{1}\right)$ : consumo ad libitum (AL) de la dieta control, de los 14 a los 42 días de edad (d); $\mathrm{P}_{2}$ : restricción cuantitativa (RCT) del 10\% del consumo AL, de los 14 a $\operatorname{los} 28$ d y consumo AL de $\operatorname{los} 29$ a los 42 d; $\mathrm{P}_{3}$ : consumo AL de los 14 a los 28 d y RCT de los 29 a los 42 d; $\mathrm{P}_{4}$ : restricción cualitativa (RCL) del 10\% en el nivel de proteína cruda y aminoácidos esenciales, de los 14 a los 28 d y consumo AL de los 29 a los 42 d de edad y P5: consumo AL de los 14 a los 28 d y RCL de los 29 a los 42 d. Los pollos del tratamiento AL ganaron más peso $(\mathrm{p} \leq 0,01)$, pero tuvieron una tasa de conversión alimenticia $(\mathrm{CA})$ similar $(\mathrm{P}>0,05)$ en comparación con los pollos de engorde sometidos a la RCT de los 29 a los 42 d. Además, los pollos de engorde alimentados con RCT de los 14 a los 28 d tuvieron menor consumo y mejor CA $(\mathrm{p} \leq 0,01)$ en comparación con el grupo de pollos de engorde alimentados con RCL de los 14 a los 28 d $\left(\mathrm{P}_{4}\right)$ y de los 29 a los 42 días de edad $\left(\mathrm{P}_{5}\right)$. Los pollos sometidos a la dieta de RCT de los 14 a los 28 d tuvieron una CA similar en comparación con las aves alimentadas AL. Una reducción del $10 \%$ en la ingesta AL de los 14 a los 28 d es una alternativa económica viable para alimentar a los pollos de engorde hasta los 42 días de edad.

Palabras clave: Aminoácidos; Análisis Económico; Consumo; Realimentación.

\section{Introduction}

The high growth rate of modern broilers is largely a result of genetic improvement programs and means a high potential for a healthy nutrient use in diets, with improvements in housing conditions with technological advances in handling. The fast growth of broilers increased greatly the yields of cuts for their later commercialization using different diets. According to Duarte et al. (2012), the yields of carcass, breast, thigh and leg quarters may be directly influenced by diets and feed programs.

Although a maximum weight of broilers at slaughter is desirable, yields of noble cuts may indicate a better efficiency of production systems in function of the evolution in weight gain and feed consumption (Ramos et al., 2011). However, problems such as accumulation of fat in the carcass and bone and metabolic dysfunctions (Zubair \& Leesson, 1996) may cause high economic losses along the broiler production chain.

One of the proposals to address problems arising from a high growth rate has been feed programs based on feed restriction. There are two practical ways of applying nutritional restriction: the qualitative, characterized by a reduction in the nutrient density of the most expensive feeds, and the quantitative, characterized by a reduction in the intake of nutrient-balanced diets (Pelicano et al., 2005).

Consumption restriction is usually applied for a short period at an age that allows weight recovery until slaughter through a compensatory gain and an increased production of low-fat carcasses, free from bone or metabolic problems, and with broiler well-being and a good economic viability.

One advantage of feed restriction programs is the stimulus for compensatory gains (Rezaei \& Hajati, 2010; Zhan et al., 2007), although it has not been proven in some studies (Khetani et al., 2009). The inconsistency of the response of birds to feed 
restriction programs has been attributed to different lineages and the duration and severity of the adopted program, factors influencing the bird's ability to recover (Mazzuco et al., 2000).

This study was developed to evaluate the performance and carcass characteristics of broilers submitted to different feed restriction programs from 14 to 42 days of age.

\section{Methodology}

The experiment methodology was approved by the Ethics Committee on Animal Use (CEUA) of the UFPB, recorded under protocol 077/2015.

\subsection{Location}

The experiment was conducted at the aviary of the Poultry Laboratory of the Department of Animal Sciences of the Center for Human, Social and Agrarian Sciences, Federal University of Paraíba, campus III, in the municipality of Bananeiras, at $6^{\circ} 45^{\prime} 00^{\prime \prime} \mathrm{S}$ and $35^{\circ} 38^{\prime} 00^{\prime \prime} \mathrm{W}$, altitude of $520 \mathrm{~m}$ above sea level.

\subsection{Animals and feed programs}

425 male Cobb $500^{\circledR}$ broilers with an average live weight of $501 \pm 2 \mathrm{~g}$ were distributed into two study periods: 14 to 28 (growth) and 29 to 42 (final) days of age. The birds were randomly assigned to five treatments with five replicates of 17 birds each.

The treatments consisted of the following feed programs (FP): Program 1 - Consumption Ad libitum (AL) of 14 to 42 days of age of a control diet (CD); Program 2 - Quantitative restriction of 10\% of AL consumption of 14 to 28 days and consumption AL of 29 to 42 days (QTR - 14 to 28 days); Program 3 - Consumption AL of 14 to 28 days with a QTR of 10\% of the AL consumption of 29 to 42 days (QTR - 29 to 42 days); Program 4 - qualitative restriction (QLR) of $10 \%$ of the broiler requirements in crude protein and essential amino acids of 14 to 28 days and AL consumption of CD of 29 to 42 days of age (QLR - 14 to 28 days); and Program 5 - AL consumption of CD of 14 to 28 days with a QLR of $10 \%$ of the of crude protein and essential amino acids requirements of 29 to 42 days of age (QLR - 29 to 42 days).

The basal diet (Table 1) was formulated to meet the nutritional requirements of broilers aiming a normal growth, according to Rostagno et al. (2011). Prior to the feed restriction period, the birds received water and feed ad libitum. 
Table 1. Feed, nutritional and energy composition of experimental diets.

\begin{tabular}{|c|c|c|c|c|c|}
\hline \multirow{2}{*}{ Ingredients } & & \multicolumn{2}{|c|}{ 14-28 days } & \multicolumn{2}{|r|}{ 29-42 days } \\
\hline & & Basal $^{1}$ & Qualitative restriction $^{2}$ & Basal $^{1}$ & Qualitative restriction $^{2}$ \\
\hline Corn & & 63.916 & 70.963 & 67.363 & 73.900 \\
\hline Soybean meal & & 31.430 & 25.490 & 27.591 & 22.073 \\
\hline Soybean oil & & 1.243 & 0.043 & 2.083 & 0.966 \\
\hline Dicalcium phosphate & & 1.365 & 1.413 & 1.075 & 1.120 \\
\hline Limestone & & 0.851 & 0.852 & 0.799 & 0.800 \\
\hline DL-Methionine & & 0.245 & 0.209 & 0.207 & 0.178 \\
\hline L-Lysine & & 0.209 & 0.245 & 0.198 & 0.235 \\
\hline L-Threonine & & 0.038 & 0.039 & 0.022 & 0.025 \\
\hline L-Valine & & 0.018 & 0.024 & 0.001 & 0.009 \\
\hline L-Arginine & & -- & 0.037 & -- & 0.035 \\
\hline Salt & & 0.456 & 0.455 & 0.431 & 0.430 \\
\hline Choline chloride & & 0.050 & 0.050 & 0.050 & 0.050 \\
\hline Vitamin premix ${ }^{3}$ & & 0.110 & 0.110 & 0.110 & 0.110 \\
\hline Mineral premix ${ }^{4}$ & & 0.060 & 0.060 & 0.060 & 0.060 \\
\hline Antoxidant $^{5}$ & & 0.010 & 0.010 & 0.010 & 0.010 \\
\hline Total & & 100.000 & 100.000 & 100.000 & 100.000 \\
\hline \multicolumn{6}{|l|}{ Calculated chemistry composition } \\
\hline Metabolizable energy & $\mathrm{kcal} / \mathrm{kg}$ & 3,000 & 3,000 & 3,100 & 3,100 \\
\hline Crude protein & $\%$ & 20.000 & 18.000 & 18.500 & 16.650 \\
\hline Digestible lysine & $\%$ & 1.100 & 0.990 & 1.000 & 0.900 \\
\hline Digestible methionine & $\%$ & 0.516 & 0.464 & 0.463 & 0.417 \\
\hline Digestible methionine + cystine & $\%$ & 0.800 & 0.720 & 0.730 & 0.657 \\
\hline Digestible arginine & $\%$ & 1.226 & 1.103 & 1.117 & 1.005 \\
\hline Digestible threonine & $\%$ & 0.715 & 0.643 & 0.650 & 0.585 \\
\hline Digestible tryptophan & $\%$ & 0.220 & 0.198 & 0.200 & 0.180 \\
\hline Digestible valine & $\%$ & 0.860 & 0.774 & 0.780 & 0.702 \\
\hline Calcium & $\%$ & 0.760 & 0.760 & 0.660 & 0.660 \\
\hline Available phosphorus & $\%$ & 0.360 & 0.360 & 0.300 & 0.300 \\
\hline Sodium & $\%$ & 0.200 & 0.200 & 0.190 & 0.190 \\
\hline Potassium & $\%$ & 0.761 & 0.672 & 0.700 & 0.618 \\
\hline Chloride & $\%$ & 0.326 & 0.327 & 0.311 & 0.312 \\
\hline Electrolyte balance & $\mathrm{mEq} / \mathrm{kg}$ & 189.7 & 166.9 & 174.1 & 152.9 \\
\hline
\end{tabular}

${ }^{1}$ Recommentations by Rostagno et al. (2011);

${ }^{2} 10 \%$ restriction in protein and amino acid levels;

${ }^{3}$ Warranty levels per kg product: 6,800,000 IU vitamin A; 1,500,000 IU vitamin D3; 12,000 IU vitamin E; 1,600 mg vitamin K3; 1,000 mg vitamin B1; 4,000 $\mathrm{mg}$ vitamin B2; 2,000 mg vitamin B6; $10,000 \mathrm{mg}$ vitamin B12; $700 \mathrm{mg}$ folic acid; $10 \mathrm{~g}$ pantothenic acid; $15 \mathrm{mg}$ biotin; $30 \mathrm{~g}$ niacin; $1.000 \mathrm{mg}$ BHT = beta hydroxy toluene.

${ }^{4}$ Warranty levels per kg product: $20 \mathrm{~g}$ copper; $96 \mathrm{~g}$ iron; $1,400 \mathrm{mg}$ iodine; $156 \mathrm{~g}$ manganese; $500 \mathrm{mg}$ selenium; $110 \mathrm{~g}$ zinc; ${ }^{5}$ Santoquim ${ }^{\circledR}$.

Source: Authors.

At 14 days of age, the birds were transferred to 25 stalls measuring $2.00 \times 1.70 \mathrm{~m}\left(3.4 \mathrm{~m}^{2}\right)$ with screen partition walls and bird-proof mesh aperture and the floor covered with shavings. Each stall was equipped with a tubular feeder and a pendulum water feeder. The experimental area was installed in a masonry shed containing side curtains, fans and nebulizers to adjust temperature and relative air humidity in order to provide comfort for the birds. A continuous lighting program was adopted throughout the experimental period using 100-watt incandescent bulbs to provide 22 lumens $/ \mathrm{m}^{2}$. A digital thermohygrometer was used to gauge and record the temperature and the relative humidity, $28 \pm 1.8^{\circ} \mathrm{C}$ and $70 \pm 2.2 \%$, respectively.

\subsection{Performance measurements}

At the end of the experimental period, feed leftovers and the broilers were weighed to evaluate feed intake, weight gain and feed conversion ratio. The feed intake was calculated by the difference between the feed provided and the leftovers obtained. 
The weight gain was determined by the difference between final and initial broiler weight, while feed conversion ratio was calculated by the ratio between feed consumption with weight gain.

\subsection{Carcass characteristics}

At 42 days of age, a total of 45 broilers, three per plot and 15 per treatment, were selected based on the mean weight, and submitted to eight hours of solids fasting. After fasting, the birds were weighed individually, desensitized by electrical stunning, and later sacrificed and eviscerated to obtain carcass weight, noble cuts weight (breast, thigh and leg quarters), edible organs weight and abdominal fat weight.

For the determination of carcass yield, we evaluated the clean and eviscerated carcass without head, legs and feet in comparison with live weight after fasting. The yields of cuts (breast, thigh and leg quarters) and edible organs (gizzard, liver and heart) were calculated by dividing the individual weight of each cut and/or organ by the carcass weight.

\subsection{Economic viability analysis and productive efficiency index}

The economic viability of the feed was evaluated considering the financial impact of feed restriction of breeding phases on the variables performance and carcass yield. The economic indexes were calculated according to the methodology described by Ramos et al. (2011) considering Feeding cost $=$ feed consumed x price of feed; Gross Revenue = number of kilograms of broiler produced $\mathrm{x}$ price of live broiler; Gross Margin $=$ average gross revenue - average feed cost; Average yield $=$ (gross margin $\div$ average feed cost) $\mathrm{x} 100$; and Relative profitability $=$ (average income of the tested program $\div$ average income of the conventional program) x 100. In addition, the productive efficiency index (PEI) was calculated, expressed by the following equation: $\mathrm{PEI}=($ average live weight $(\mathrm{g}) \mathrm{x}$ bird viability $(\%)) \div\left(\right.$ broiler age (days) $\mathrm{x}$ feed conversion ratio $\left.\left(\mathrm{g} \mathrm{g}^{-1}\right)\right) \times 100$.

The prices of the ingredients used to prepare the economic analysis were acquired from the local market, as well as the price of live broilers, while the amino acids were obtained from suppliers considering the daily dollar exchange rate (US\$ 3.1029).

\subsection{Statistical analysis}

The data were analyzed by the GLM procedure using the software Statistical Analysis System (version 9.3, 2012, SAS Institute Inc., Cary, NC). Then, the means of the treatments were interpreted by Student-Newman-Kuels test considering a probability of $5 \%$ and orthogonal contrasts.

\section{Results}

\subsection{Performance}

The performance of broilers from 14 to 42 days of age were influenced $(\mathrm{p} \leq 0.05)$ by feed programs (Table 2 ). 
Table 2. Performance of broilers fed with different feed programs from 14 to 42 days of age.

\begin{tabular}{|c|c|c|c|}
\hline \multirow{2}{*}{ Feed program ${ }^{1}$} & Feed intake & Weight gain & Feed conversion ratio \\
\hline & $(\mathrm{g})$ & $(\mathrm{g})$ & $\left(\mathrm{g} / \mathrm{g}^{-1}\right)$ \\
\hline AL-14 a 42 d & $4,070 \pm 82^{\mathrm{A}}$ & $2,290 \pm 34^{\mathrm{A}}$ & $1,777 \pm 0.02^{\mathrm{AB}}$ \\
\hline QTR-14-28 d & $3,888 \pm 96^{\mathrm{B}}$ & $2,229 \pm 58^{\mathrm{A}}$ & $1,745 \pm 0.05^{\mathrm{B}}$ \\
\hline QTR -29-42 d & $3,824 \pm 91^{\mathrm{B}}$ & $2,126 \pm 76^{\mathrm{B}}$ & $1,799 \pm 0.03^{\mathrm{A}}$ \\
\hline QLR-14-28 d & $4,101 \pm 88^{\mathrm{A}}$ & $2,253 \pm 77^{\mathrm{A}}$ & $1,821 \pm 0.04^{\mathrm{A}}$ \\
\hline QLR -29-42 d & $4,163 \pm 5^{\mathrm{A}}$ & $2,279 \pm 30^{\mathrm{A}}$ & $1,827 \pm 0.02^{\mathrm{A}}$ \\
\hline MSE & 30.4 & 16.0 & 0.01 \\
\hline$P$-value & $<0.001$ & 0.002 & 0.003 \\
\hline \multicolumn{4}{|l|}{ Contrasts } \\
\hline $\mathrm{AL}^{2} v s$ Others & ns & 2,290 vs $2,222 *$ & ns \\
\hline AL vs QTR & 4,070 vs $3,856^{* *}$ & 2,290 vs $2,178^{*}$ & ns \\
\hline $\mathrm{AL} v s \mathrm{QLR}$ & $\mathrm{ns}$ & $\mathrm{ns}$ & 1,777 vs $1,840^{*}$ \\
\hline QTR vs QLR & 3,856 vs $4,132 * *$ & 2,178 vs $2,249 *$ & 1,772 vs $1,840^{*}$ \\
\hline
\end{tabular}

${ }^{\mathrm{AB}}$ Means within columns differed by SNK test $(\mathrm{p}<0.05)$; Probability $* *(\mathrm{p}<0.01)$;

${ }^{1}$ Program $1\left(\mathrm{P}_{1}\right)$ : consumption ad libitum (AL) of a control diet of 14 to 42 days of age; $\mathrm{P}_{2}$ : quantitative restriction (QTR) of $10 \%$ of consumption AL of a control diet (CD) of 14 to 28 days and consumption AL of 29 to 42 days; $\mathrm{P}_{3}$ : consumption AL of 14 to 28 days with QTR of $10 \%$ of consumption AL of 29 to 42 days; $\mathrm{P}_{4}$ : qualitative restriction (QLR) of $10 \%$ of crude protein (CP) and essential amino acids (EAAs) levels of 14 to 28 days and consumption AL of CD of 29 to 42 days of age; and $\mathrm{P}_{5}$ : consumption AL of CD of 14 to 28 days with QLR in 10\% of CP and EAAs levels of 29 to 42 days of age.

$\mathrm{MSE}=$ mean standard error

Source: Authors.

\subsubsection{Quantitative and qualitative feed restriction programs}

Broilers submitted to a quantitative restriction of $10 \%$ of Ad libitum consumption of control diet of 14 to 28 days presented a lower $(\mathrm{p} \leq 0.001)$ feed intake, but a similar weight gain and feed conversion ratio $(\mathrm{P}>0.05)$ compared with birds fed AL 14 to 42 days. While the groups of broilers submitted to qualitative food restriction programs of $10 \%$ of protein and essential amino acids of 14 to 28 days or of 29 to 42 days did not change the feed intake, weight gain and feed conversion ratio in comparison with birds fed AL of 14 to 42 days $(\mathrm{P}>0.05)$.

The quantitative restriction program did not follow the suggestion of avoiding reductions in feed supply two weeks before slaughter, because it would have negative implications on the performance of broiler chickens. Despite this, a similar feed conversion ratio $(\mathrm{P}<0.05)$ was observed for birds under feed restriction during the finishing phase (29 to 42 days) in comparison to AL supply, although with low weight gain and expected consumption.

\subsubsection{Tests of contrasts between feeding programs}

The analysis of orthogonal contrasts showed that broilers consuming the control diet supplied AL of 14 to 42 days presented a higher weight gain $(\mathrm{p} \leq 0.01)$ than broilers fed all feed program $(2,290 v s 2,222 \mathrm{~g})$, but feed intake and feed conversion ratio were similar $(\mathrm{P}>0.05)$.

Broilers fed with $90 \%$ of ad libitum consumption expressed lower ( $\mathrm{p} \leq 0.01)$ feed intake $(3,856$ vs 4,070 g) and weight gain (2,178 vs $2.290 \mathrm{~g})$ in comparison with birds fed control diet ad libitum.

Broilers fed control diet ad libitum had a better feed conversion ratio $(\mathrm{p} \leq 0.01)$ than broilers fed qualitative feed restriction (1,777 vs 1,840 g g-1201). However, feed intake and weight gain were similar between birds receiving ad libitum feed and qualitative feed restriction $(\mathrm{P}>0.05)$.

The qualitative feed restriction stimulated feed intake ( $\mathrm{p} \leq 0.001)(4,132$ vs $3,856 \mathrm{~g})$, which led to a greater weight gain $(\mathrm{P} \leq 0.01)(2,249 v s 2,178 \mathrm{~g})$ and a worse feed conversion ratio $(\mathrm{p} \leq 0.01)\left(1,840 v s 1,172 \mathrm{~g} \mathrm{~g}^{-1}\right)$ compared to broilers fed quantitative feed restriction, respectively. 


\subsection{Carcass and noble cuts yields}

Carcass and noble cuts yields were not affected by feeding programs ( $\mathrm{P}>0.05)$ up to 42 days of age (Table 3), although breast yields changed according with the orthogonal contrast among AL vs All program and AL vs QTR.

Broilers fed ad libitum presented a higher breast yield $(\mathrm{p} \leq 0.05)$ in comparison of average of all treatments $(45.52 \mathrm{vs}$ $38.94 \%$ ) and broilers fed with feed restriction of $10 \%$ of ad libitum program (45.52 vs 38.56\%).

Table 3. Values of carcass and noble cuts yields of broilers at 42 days of age fed with different feeding programs

\begin{tabular}{|c|c|c|c|c|}
\hline \multirow{2}{*}{ Feed program ${ }^{1}$} & Carccass & Breast & Thigh & Leg quartes \\
\hline & $---\%---$ & \multicolumn{3}{|c|}{---------\% \%--------- } \\
\hline AL-14 a $42 \mathrm{~d}$ & $77.48 \pm 0.8$ & $40.52 \pm 0.7$ & $12.16 \pm 0.4$ & $14.83 \pm 0.6$ \\
\hline QTR-14-28 d & $76.83 \pm 1.2$ & $38.89 \pm 1.5$ & $11.90 \pm 0.6$ & $14.60 \pm 0.7$ \\
\hline QTR -29-42 d & $77.05 \pm 1.0$ & $38.24 \pm 1.9$ & $12.01 \pm 0.8$ & $14.55 \pm 0.6$ \\
\hline QLR-14-28 d & $76.67 \pm 0.7$ & $40.15 \pm 0.8$ & $11.96 \pm 0.4$ & $14.09 \pm 0.6$ \\
\hline QLR -29-42 d & $78.67 \pm 2.9$ & $38.47 \pm 1.6$ & $12.08 \pm 0.2$ & $13.84 \pm 0.6$ \\
\hline MSE & 0.32 & 0.31 & 0.09 & 0.14 \\
\hline$P$-value & 0.281 & 0.054 & 0.937 & 0.119 \\
\hline \multicolumn{5}{|l|}{ Contrasts } \\
\hline $\mathrm{AL}^{2} v s$ Others & $\mathrm{ns}$ & 45.52 vs $38.94 *$ & $\mathrm{~ns}$ & $\mathrm{~ns}$ \\
\hline AL vs QTR & ns & 45.52 vs $38.56^{*}$ & ns & ns \\
\hline AL vs QLR & ns & $\mathrm{ns}$ & ns & ns \\
\hline QTR vs QLR & ns & ns & ns & ns \\
\hline
\end{tabular}

${ }^{\mathrm{AB}}$ Means within columns differed by SNK test $(\mathrm{p}<0.05)$; Probability $* *(\mathrm{p}<0.01)$;

${ }^{1}$ Program $1\left(\mathrm{P}_{1}\right)$ : consumption ad libitum (AL) of a control diet of 14 to 42 days of age; $\mathrm{P}_{2}$ : quantitative restriction (QTR) of $10 \%$ of consumption AL of a control diet (CD) of 14 to 28 days and consumption AL of 29 to 42 days; $\mathrm{P}_{3}$ : consumption AL of 14 to 28 days with QTR of $10 \%$ of consumption AL of 29 to 42 days; $\mathrm{P}_{4}$ : qualitative restriction (QLR) of $10 \%$ of crude protein (CP) and essential amino acids (EAAs) levels of 14 to 28 days and consumption AL of CD of 29 to 42 days of age; and $\mathrm{P}_{5}$ : consumption AL of CD of 14 to 28 days with QLR in $10 \%$ of CP and EAAs levels of 29 to 42 days of age.

$\mathrm{MSE}=$ mean standard error.

Source: Authors.

\subsection{Weights and yields of edible organs and fat yield}

The weights and yields of edible organs were not affected by feeding programs ( $\mathrm{P}>0.05)$, as shown in Table 4 .

Table 4. Weights and yields of edible organs of broilers at 42 days of age subjected to diets with different feeding programs.

\begin{tabular}{|c|c|c|c|c|c|c|}
\hline \multirow{2}{*}{ Feed program ${ }^{1}$} & Heart & Gizzard & Liver & Heart & Gizzard & Liver \\
\hline & \multicolumn{3}{|c|}{------grams----- } & \multicolumn{3}{|c|}{------\%------ } \\
\hline AL-14 a $42 \mathrm{~d}$ & $11.0 \pm 1.0$ & $30.8 \pm 2.7$ & $41.3 \pm 4.1$ & $0.52 \pm 0.04$ & $1.44 \pm 0.09$ & $1.98 \pm 0.20$ \\
\hline QTR-14-28 d & $10.7 \pm 1.3$ & $29.8 \pm 2.2$ & $40.7 \pm 1.7$ & $0.53 \pm 0.06$ & $1.47 \pm 0.17$ & $1.95 \pm 0.08$ \\
\hline QTR -29-42 d & $9.9 \pm 1.3$ & $30.1 \pm 0.4$ & $42.2 \pm 3.2$ & $0.48 \pm 0.05$ & $1.51 \pm 0.10$ & $2.02 \pm 0.15$ \\
\hline QLR-14-28 d & $10.3 \pm 1.0$ & $30.1 \pm 3.0$ & $38.5 \pm 3.4$ & $0.51 \pm 0.05$ & $1.48 \pm 0.12$ & $1.85 \pm 0.16$ \\
\hline QLR -29-42 d & $10.7 \pm 1.1$ & $28.7 \pm 1.0$ & $45.3 \pm 5.9$ & $0.52 \pm 0.06$ & $1.39 \pm 0.03$ & $2.06 \pm 0.10$ \\
\hline MSE & 0.20 & 0.40 & 0.60 & 0.01 & 0.02 & 0.03 \\
\hline$P$-value & 0.3778 & 0.6832 & 0.6567 & 0.5181 & 0.2371 & 0.2367 \\
\hline \multicolumn{7}{|l|}{ Contrasts } \\
\hline $\mathrm{AL}^{2} v s$ Too & $\mathrm{ns}$ & $\mathrm{ns}$ & $\mathrm{ns}$ & $\mathrm{ns}$ & ns & ns \\
\hline AL vs QTR & ns & ns & ns & ns & ns & ns \\
\hline AL vs QLR & ns & ns & ns & ns & ns & ns \\
\hline QTR vs QLR & ns & ns & ns & ns & ns & ns \\
\hline
\end{tabular}

${ }^{\mathrm{AB}}$ Means within columns differed by SNK test $(\mathrm{p}<0.05)$; Probability $* *(\mathrm{p}<0.01)$;

${ }^{1}$ Program $1\left(\mathrm{P}_{1}\right)$ : consumption ad libitum (AL) of a control diet of 14 to 42 days of age; $\mathrm{P}_{2}$ : quantitative restriction (QTR) of $10 \%$ of consumption AL of a control diet (CD) of 14 to 28 days and consumption AL of 29 to 42 days; $\mathrm{P}_{3}$ : consumption AL of 14 to 28 days with QTR of $10 \%$ of consumption AL of 29 to 42 days; $\mathrm{P}_{4}$ : qualitative restriction (QLR) of $10 \%$ of crude protein (CP) and essential amino acids (EAAs) levels of 14 to 28 days and consumption AL of CD of 29 to 42 days of age; and $\mathrm{P}_{5}$ : consumption AL of CD of 14 to 28 days with QLR in $10 \%$ of CP and EAAs levels of 29 to 42 days of age.

MSE $=$ mean standard error.

Source: Authors. 
Broilers that received the diet ad libitum and broilers subjected to quantitative restrictions of 29 to 42 days and qualitative restrictions, regardless of stage, presented a similar abdominal fat yield, while broilers treated with quantitative restriction of 14 to 28 days had a greater fat yield in the carcass (Figure 1).

Figure 1. Percentage of abdominal fat of broilers at 42 days submitted to diets with different feeding programs ${ }^{1}$.

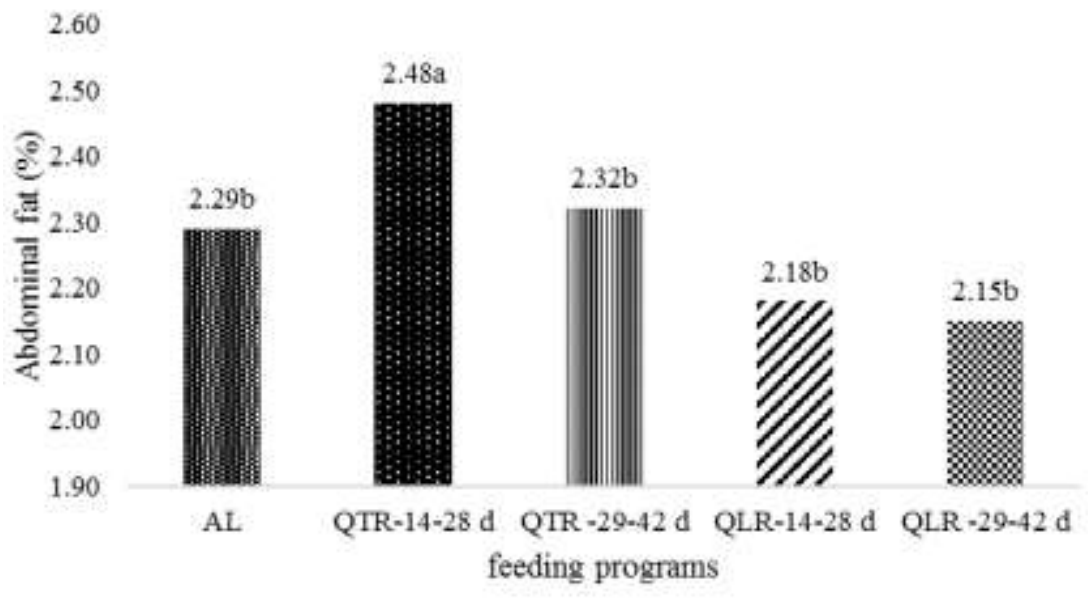

${ }^{\mathrm{AB}}$ Means within columns differed by SNK test $(\mathrm{p}<0.05)$; Probability ** $(\mathrm{p}<0.01)$;

${ }^{1}$ Program $1\left(\mathrm{P}_{1}\right)$ : consumption ad libitum (AL) of a control diet of 14 to 42 days of age; $\mathrm{P}_{2}$ : quantitative restriction (QTR) of $10 \%$ of consumption AL of a control diet (CD) of 14 to 28 days and consumption AL of 29 to 42 days; $\mathrm{P}_{3}$ : consumption AL of 14 to 28 days with QTR of $10 \%$ of consumption AL of 29 to 42 days; $\mathrm{P}_{4}$ : qualitative restriction (QLR) of $10 \%$ of crude protein (CP) and essential amino acids (EAAs) levels of 14 to 28 days and consumption AL of CD of 29 to 42 days of age; and $\mathrm{P}_{5}$ : consumption AL of CD of 14 to 28 days with QLR in 10\% of CP and EAAs levels of 29 to 42 days of age.

MSE $=$ mean standard error.

$\mathrm{P}$-value $=0.0003 ; \mathrm{MSE}=0.03$.

Source: Authors.

\subsection{Economic evaluation of feed programs}

The average cost of conventional diets and qualitative restrictions was higher $(\mathrm{p}<0.05)$ than the quantitative restriction program (Table 5).

Table 5. Average economic viability indexes of broilers subjected to different feeding programs.

\begin{tabular}{|c|c|c|c|c|c|c|}
\hline \multirow[t]{2}{*}{ Feed program ${ }^{1}$} & $\begin{array}{c}\text { Feeding } \\
\text { Cost }\end{array}$ & $\begin{array}{c}\text { Gross } \\
\text { Revenue }\end{array}$ & $\begin{array}{c}\text { Gross } \\
\text { Margin }\end{array}$ & $\begin{array}{c}\text { Average } \\
\text { yield }\end{array}$ & $\begin{array}{c}\text { Relative } \\
\text { profitability }\end{array}$ & \multirow{2}{*}{$\begin{array}{c}\text { productive } \\
\text { efficiency index }\end{array}$} \\
\hline & \multicolumn{3}{|c|}{---- (US\$/ave) } & \multicolumn{2}{|c|}{$---\%$--- } & \\
\hline AL-14 a $42 \mathrm{~d}$ & $11.955^{\mathrm{A}}$ & $23.362^{\mathrm{A}}$ & $11.407^{\mathrm{AB}}$ & $95.42^{\mathrm{B}}$ & $100.00^{\mathrm{AB}}$ & $369.21^{\mathrm{A}}$ \\
\hline QTR-14-28 d & $11.413^{\mathrm{B}}$ & $22.892^{\mathrm{A}}$ & $11.479^{\mathrm{A}}$ & $100.58^{\mathrm{A}}$ & $105.41^{\mathrm{A}}$ & $364.20^{\mathrm{A}}$ \\
\hline QTR -29-42 d & $11.239^{\mathrm{B}}$ & $22.036^{\mathrm{B}}$ & $10.797^{\mathrm{B}}$ & $96.07^{\mathrm{B}}$ & $100.68^{\mathrm{AB}}$ & $327.37^{\mathrm{B}}$ \\
\hline QLR-14-28 d & $12.050^{\mathrm{A}}$ & $23.106^{\mathrm{A}}$ & $11.056^{\mathrm{AB}}$ & $91.75^{\mathrm{B}}$ & $96.16^{\mathrm{B}}$ & $339.40^{\mathrm{B}}$ \\
\hline QLR -29-42 d & $12.227^{\mathrm{A}}$ & $23.307^{\mathrm{A}}$ & $11.080^{\mathrm{AB}}$ & $90.62^{\mathrm{B}}$ & $94.97^{\mathrm{B}}$ & $358.41^{\mathrm{A}}$ \\
\hline$P$-value & 0.001 & 0.003 & 0.076 & 0.001 & 0.045 & 0.004 \\
\hline
\end{tabular}

${ }^{\mathrm{AB}}$ Means within columns differed by SNK test $(\mathrm{p}<0.05)$; Probability $* *(\mathrm{p}<0.01)$;

${ }^{1}$ Program $1\left(\mathrm{P}_{1}\right)$ : consumption ad libitum (AL) of a control diet of 14 to 42 days of age; $\mathrm{P}_{2}$ : quantitative restriction (QTR) of $10 \%$ of consumption AL of a control diet (CD) of 14 to 28 days and consumption AL of 29 to 42 days; $\mathrm{P}_{3}$ : consumption AL of 14 to 28 days with QTR of $10 \%$ of consumption AL of 29 to 42 days; $\mathrm{P}_{4}$ : qualitative restriction (QLR) of $10 \%$ of crude protein (CP) and essential amino acids (EAAs) levels of 14 to 28 days and consumption AL of CD of 29 to 42 days of age; and $\mathrm{P}_{5}$ : consumption AL of CD of 14 to 28 days with QLR in $10 \%$ of CP and EAAs levels of 29 to 42 days of age.

Source: Authors.

The mean gross income of the control diet supplied ad libitum of 14 to 42 days was higher ( $\mathrm{p} \leq 0.05)$ only for the treatment with a quantitative restriction of $10 \%$ of consumption ad libitum of 29 to 42 days $(24,699$ vs 23,297 US\$/bird). 
The mean gross margin of the group of broilers subjected to quantitative restriction of $10 \%$ of consumption ad libitum of 14 to 28 days was higher $(\mathrm{p} \leq 0.05)$ than broilers subjected to $10 \%$ of ad libitum consumption of 29 to 42 days $(11,479$ vs $10,797 \mathrm{US} \$ /$ bird), with a similarity of results in comparison to other feed programs.

The average profitability of broilers subjected to a quantitative restriction of $10 \%$ of ad libitum consumption of 14 to 28 days was higher $(\mathrm{p} \leq 0.05)$ than the other feed programs, including the ad libitum consumption. The relative profitability of broilers fed $10 \%$ of ad libitum consumption of 14 to 28 days exceeded by $5 \%$, numerically, the relative profitability of broilers that consumed feed ad libitum.

The European productive efficiency index (PEI), a reference standard for economic efficiency analysis of broiler breeding, showed similar results $(\mathrm{P}>0.05)$ between the feed program ad libitum and the quantitative restriction of $10 \%$ of $a d$ libitum consumption of 14 to 28 days, which performed better $(\mathrm{p} \leq 0.05)$ than broilers with a quantitative restriction diet of 29 to 42 days and a qualitative restriction diet of 14 to 28 days of age.

\section{Discussion}

Early feed restriction of broilers is usually used to induce growth and improve nutrient use efficiency (Susbilla et al., 2003). The restricted feeding programs are normally imposed by physical restriction of feed or the feeding of diets with a low nutrient density (Yagoub \& Babiker, 2008). We choose the two methods of feed restriction to evaluate comparatively in this study.

The feed intake of birds fed nutrient restriction diet was highest when compared of birds fed quantitative feed restriction. The possibility of birds to increase feed intake in response of offer of ad libitum marginal low concentration essential nutrients diet was the pivotal factor of this result. Esmail (2018) commented that the birds tend to increase their feed intake to make up for deficiencies when fed with diets that are marginally deficient in crude protein. According to Guyton and Hall (2011), the increase in consumption may be explained by the fact that the animal's appetite is controlled by its nutritional status, that is, when the availability of nutrients decreases, the organism automatically increases food intake in response to stimuli from the hunger center in the lateral hypothalamus.

The highest weight gain of broilers subjected to qualitative feed restriction versus broilers subjected to a quantitative feed restriction in this study corroborate with Butzen et al. (2013), who also observed a greater weight gain in broilers treated with a qualitative feed restriction from 8 to 16 days of age.

The restriction in the amount of feed have a negative impact on weight gain, but the restriction of essential nutrient affects more the feed conversion ratio. The broilers fed quantitative restriction diet of 14 to 28 days presented a similar feed conversion ratio to birds fed ad libitum, and better compared to the broilers fed diet with qualitative restriction (Table 2). The better feed conversion ratio in birds fed diet with quantitative restriction may be associated with a reduced need for maintenance energy related to a low body weight and metabolic adaptation (Yu \& Robinson, 1992). Jordão Filho et al. (2011) met same relationship among low feed intake and better feed conversion ratio, and showed that birds with low feed intake had smaller maintenance requirements than birds fed diet in voluntary feed intake. Also Butzen et al. (2013) observed better feed conversion ratio for broilers receiving feed with quantitative restriction in comparison with the supply ad libitum.

In our study, with quantitative food restriction of $10 \%$ of consumption ad libitum, a feed conversion ratio value similar to the control (ad libitum). On the other hand, several studies demonstrate the improvement of feed conversion ratio and reduction of feed costs with the use of food restriction programs (Abdel-Hafeez et al., 2016; Bordin et al., 2021). In this case, it is suggested that the lack of significant difference for feed conversion ratio between the control diet and the quantitative feed restriction, may be due to a low severity of feed restriction (10\% reduction in ad libitum consumption). 
In a study with different levels of feed restriction in broilers, Rahimi et al. (2015), obtained better feed conversion ratio according to the increase in the percentage of feed restriction in relation to the control treatment, possibly due to the reduced time available for digestion (Bordin et al., 2021). At the same time, birds with feed restriction may have adequate time to use feed nutrients more efficiently, leading to better feed conversion than birds fed ad libitum (Abdel-Hafeez et al., 2016). Adeyemi et al. (2015) and Trocino et al. (2020) observed that birds submitted to the stress of food restriction stay longer near the feeder, have a potential to use their feed more efficiently in relation to those with ad libitum feed.

There are effects of feed restriction on carcass and noble cuts yields compared of results of broilers fed ad libitum. These data corroborate those reported by Hassanien (2011), Tesfaye et al. (2011) and Jalal and Zakaria (2012). However, both forms of feed restriction provided a low breast yield compared to broilers fed ad libitum. It is probable that the reduction in breast yield of birds with restricted feed may be due to a decreased amino acid intake. The results suggest that the growth rate of broilers is related to nutrient intake, which supports the statement of O'sullivan, Dunnington and Siegel (1992), for whom the improvement in the body weight of birds is correlated to feed consumption.

Weights and yields of edible organs are similar among broilers with and without feed restriction, regardless of the restriction methodology applied. The results of this study are in agreement with Hassanien (2011), Tesfaye et al. (2011), Jalal and Zakaria (2012) and Van der Klein et al. (2017). It appears that the organs of the gastrointestinal tract are spared from the effects of food restriction depending on animal age and duration of the restriction period (Ferraris et al., 2001).

The results for abdominal fat yield (Figure 1) of the group of birds that received a quantitative restriction of $10 \%$ of consumption ad libitum of 14 to 28 days was highest than of the groups of birds fed others treatments of restrictions or fed ad libitum. The no agreement with those results reported by Boostani et al. (2010) and Shabani et al. (2015), who did not observe differences in abdominal fat yield among broilers fed with restriction or ad libitum. Disagreeing with the results of present study, Jalal and Zakaria (2012) and Mirshamsollahi (2013) determined that diet restriction reduced abdominal fat yield, the activity of lipogenic enzymes are depressed during the feed restriction period, peaking during the first week of re-feeding, and gradually reducing in the subsequent weeks.

The average cost of broiler feed with a quantitative restriction of $10 \%$ of consumption ad libitum was lower than that of other feeding programs. This is justified by a low feed intake. The similarity in the gross income of broilers subjected to quantitative feed restriction of 14 to 28 days with that of broilers subjected to consumption ad libitum was due to weight gain. It resulted in an at least similar gross margin between feed programs. The broilers that provided the highest profitability were subjected to a quantitative restriction of $10 \%$ of consumption ad libitum of 14 to 28 days of age (p<0.05). Because of a lower cost of feed, they yielded 5\% more than birds subjected to consumption ad libitum.

The relative profitability index and the productive efficiency index presented results similar to those of broilers fed with a quantitative restriction of $10 \%$ of consumption ad libitum of 14 to 28 days and broilers fed at will. Novel et al. (2009) and Hassanien (2011) reported that the level of food restriction provided an economic advantage over broilers fed ad libitum, mainly by an efficient nutrient use. This denotes the possibility of applying a restriction plan in the intermediate phase of production, reducing costs and avoiding bone and metabolic problems.

\section{Conclusion}

In conclusion, a $10 \%$ reduction in ad libitum consumption over the period from 14 to 28 days is an economically viable alternative to feed broilers up to 42 days of age. 


\section{Acknowledgments}

The authors would like to thank the Coordination for the Improvement of Higher Education Personnel (CAPES) for the granting the scholarship.

\section{References}

Abdel-Hafeez, H. M., Saleh, E. S., Tawfeek, S. S., Youssef, I. M., \& Abdel-Daim, A. S. (2017). Effects of probiotic, prebiotic, and synbiotic with and without feed restriction on performance, hematological indices and carcass characteristics of broiler chickens. Asian-Australasian Journal of Animal Sciences, 30(5), 672 .

Adeyemi, O. A., Njoku, C. P., Odunbaku, O. M., Sogunle, O. M., \& Egbeyale, L. T. (2015). Response of broiler chickens to quantitative feed restriction with or without ascorbic acid supplementation. Iranian Journal of Applied Animal Science, 5(2), 393-401.

Boostani, A., Ashayerizadeh, A., Mahmoodian, F. H., \& Kamalzadeh, A. (2010). Comparison of the effects of several feed restriction periods to control ascites on performance, carcass characteristics and hematological indices of broiler chickens. Brazilian Journal of Poultry Science, 12(3), $170-177$.

Bordin, T., Pilotto, F., Pesenatto, D., de Mendonça, B. S., Daroit, L., Rodrigues, L. B., \& Dickel, E. L. (2021). Performance of broiler chicken submitted to a quantitative feed restriction program. Tropical Animal Health and Production, 53(1), 1-5.

Butzen, F. M., Ribeiro, A. M. L., Vieira, M. M., Kessler, A. M., Dadalt, J. C., \& Della, M. P. (2013). Early feed restriction in broilers. I-Performance, body fraction weights, and meat quality. Journal of Applied Poultry Research, 22(2), 251-259.

Duarte, K. F., Junqueira, O. M., Borges, L. L., Santos, E. T., Marques, R. H., de Quadros, T. C. O., \& Domingues, C. H. D. F. (2012). Desempenho e morfometria duodenal de frangos de corte submetidos a diferentes níveis de energia e programas de alimentação de 42 a 57 dias de idade. Ciência Animal Brasileira, 13(2), 197-204.

Esmail, S. (2018). Feed restriction in broiler production. Poultry World, 34(2), 12-15.

Ferraris, R. P., Cao, Q. X., \& Prabhakaram, S. (2001). Chronic but not acute energy restriction increases intestinal nutrient transport in mice. The Journal of Nutrition, 131(3), 779-786.

Guyton, A. C. \& Hall, J. E (2011). Tratado de fisiologia médica. (12a ed.), Elsevier Brasil, 867-868.

Hassanien, H. H. M. (2011). Productive performance of broiler chickens as affected by feed restriction systems. Asian Journal of Poultry Science, 5(1), 21-27.

Jalal, M. A., \& Zakaria, H. A. (2012). The effect of quantitative feed restriction during the starter period on compensatory growth and carcass characteristics of broiler chickens. Pakistan Journal of Nutrition, 11(9), 719.

Jordão Filho, J., Silva, J. H. V. D., Silva, C. T., Costa, F. G. P., Sousa, J. M. B. D., \& Givisiez, P. E. N. (2011). Energy requirement for maintenance and gain for two genotypes of quails housed in different breeding rearing systems. Revista Brasileira de Zootecnia, 40(11), $2415-2422$.

Khetani, T. L., Nkukwana, T. T., Chimonyo, M., \& Muchenje, V. (2009). Effect of quantitative feed restriction on broiler performance. Tropical Animal Health and Production, 41(3), 379-384.

Mazzuco, H., Guidoni, A. L., \& Jaenisch, F. R. (2000). Efeito da restrição alimentar qualitativa sobre o ganho compensatório em frangos de corte. Pesquisa Agropecuária Brasileira, 35, 543-549.

Mirshamsollahi, A. (2013). Effect of different food restriction on performance and carcass characteristics of Arian and Ross broiler chicks. International Journal of Agriculture, 3(3), 495.

Novel, D. J., Ng'Ambi, J. W., Norris, D., \& Mbajiorgu, C. A. (2009). Effect of different feed restriction regimes during the starter stage on productivity and carcass characteristics of male and female Ross 308 broiler chickens. Int. J. Poult. Sci, 8(1), 35-39.

O'sullivan, N. P., Dunnington, E. A., \& Siegel, P. B. (1992). Correlated Responses in Lines of Chickens Divergently Selected for Fifty-Six-Day Body Weight. 1. Growth, Feed Intake, and Feed Utilization. Poultry science, 71(4), 590-597.

Pelicano, E. R. L., Bernal, F. E. M., Furlan, R. L., Malheiros, E. B., \& Macari, M. (2005). Efeito da temperatura ambiente e da restrição alimentar protéica ou energética sobre o ganho de peso e crescimento ósseo de frangos de corte. Arquivo Brasileiro de Medicina Veterinária e Zootecnia, $57,353-360$.

Rahimi, S., Seidavi, A., Sahraei, M., Blanco, F. P., Schiavone, A., \& Martínez Marín, A. L. (2015). Effects of feed restriction and diet nutrient density during re-alimentation on growth performance, carcass traits, organ weight, blood parameters and the immune response of broilers. Italian Journal of Animal Science, $14(3), 4037$.

Ramos, K. C. B. T., da Costa Gomes, A. V., de Lima, C. A. R., Camargo, A. M., Curvello, F. A., Silva, R. V. M. M., \& de Andrade Massi, P. (2011). Desempenho produtivo e econômico de frangos de corte submetidos a programas de restrição alimentar. Ciência Animal Brasileira, 12(1), 08-16.

Rezaei, M., \& Hajati, H. (2016). Effect of diet dilution at early age on performance, carcass characteristics and blood parameters of broiler chicks. Italian Journal of Animal Science.

Rostagno, H. S., Albino, L., Donzele, J. L., Gomes, P. C., De Oliveira, R. F., Lopes, D. C., \& Euclides, R. (2011). Tabelas brasileiras para suínos e aves: composição de alimentos e exigências nutricionais (HS Rostagno. In (3rd ed.), UFV. 
Research, Society and Development, v. 10, n. 12, e339101220447, 2021 (CC BY 4.0) | ISSN 2525-3409 | DOI: http://dx.doi.org/10.33448/rsd-v10i12.20447

Shabani, S., Seidavi, A., Asadpour, L., \& Corazzin, M. (2015). Effects of physical form of diet and intensity and duration of feed restriction on the growth performance, blood variables, microbial flora, immunity, and carcass and organ characteristics of broiler chickens. Livestock Science, $180,150-157$.

Susbilla, J. P., Tarvid, I., Gow, C. B., \& Frankel, T. L. (2003). Quantitative feed restriction or meal-feeding of broiler chicks alter functional development of enzymes for protein digestion. British Poultry Science, 44(5), 698-709.

Tesfaye, E., Tamir, B., Haile, A., \& Dessie, T. (2011). Effect of skip-a-day feed restriction on carcass yield characteristics and economic advantages of Rhode Island Red pullets. African Journal of Agricultural Research, 6(4), 849-855.

Trocino, A., Piccirillo, A., Birolo, M., Radaelli, G., Bertotto, D., Filiou, E., \& Xiccato, G. (2015). Effect of genotype, gender and feed restriction on growth, meat quality and the occurrence of white striping and wooden breast in broiler chickens. Poultry science, 94(12), 2996-3004..

Van der Klein, S. A. S., Silva, F. A., Kwakkel, R. P., \& Zuidhof, M. J. (2017). The effect of quantitative feed restriction on allometric growth in broilers. Poultry Science, 96(1), 118-126.

Yagoub, M. Y. \& Babiker, S. A. (2008). A. Effect of compensatory growth on the performance and carcass characteristics of the broiler chicks. Pakistan Journal of Nutrition, 7(3), 497-499.

Yu, M. W., \& Robinson, F. E. (1992). The application of short-term feed restriction to broiler chicken production: a review. Journal of Applied Poultry Research, $1(1), 147-153$.

Zhan, X. A., Wang, M., Ren, H., Zhao, R. Q., Li, J. X., \& Tan, Z. L. (2007). Effect of early feed restriction on metabolic programming and compensatory growth in broiler chickens. Poultry Science, 86(4), 654-660.

Zubair, A. K., \& Leeson, S. (1996). Compensatory growth in the broiler chicken: a review. World's Poultry Science Journal, 52(2), $189-201$. 